\title{
Skeletal Factors Related to Open Lock of the Temporomandibular Joint
}

\author{
Ji-Na Nam, D.D.S., Jeong-Yun Lee, D.D.S.,Ph.D. \\ Dept. of Oral Medicine and Oral Diagnosis, School of Dentistry \& Dental Research Institute, \\ Seoul National University, Seoul, Korea (ROK)
}

\begin{abstract}
This study was performed to investigate the skeletal factors related to open lock of the temporomandibular joint(TMJ). We compared the skeletal measurements on the cephalogram and transcranial radiograph among 3 groups, open lock group consisting of consecutively filed 50 patients with at least one open lock episode within recent 1 year, temporomandibular disorder(TMD) group of 50 TMD patients without open lock diagnosed by Research Diagnostic Criteria for TMD (RDC/TMD) Axis I, and normal group of 50 patients without TMD or open lock. The patients of TMD and normal group were randomly selected in an age-and-gender-matched way with ones of open lock group. Open lock group showed smaller saddle angle than normal group on cephalograms and steeper inclination of the articular eminence than TMD and normal groups on transcranial radiographs. These results imply that the patients with the joint located more anterior and the articular eminence with steeper inclination might be riskier to TMJ open lock.
\end{abstract}

Key words : Temporomandibular joint, Temporomandibular disorder, Open lock, Dislocation, Articular eminence

\section{I . INTRODUCTION}

Temporomandibular disorder(TMD) is a collective term embracing a number of clinical problems that involve the masticatory musculature, the temporomandibular joint(TMJ) and associated structures. ${ }^{1,2)}$ These disorders are characterized by facial pain in

Corresponding author: Dr. Jeong-Yun Lee Associate Professor

Dept. of Oral Medicine and Oral Diagnosis

School of Dentistry\& Dental Research Institute

Seoul National University

Daehakro-101, Jongno-Gu, Seoul 110-749

Korea (ROK)

Tel: +82-2-2072-0212

Fax: +82-2-744-9135

E-mail: jeongyun@snu.ac.kr

Received: 2013-06-10

Revised: 2013-07-16

Accepted: 2013-08-05 the region of the TMJ and the masticatory muscles, limitation or deviation in the mandibular range of motion, or TMJ sounds during jaw movement and function. ${ }^{3)}$ TMJ dislocation or open lock, one of the TMD, has been described mainly in terms of an excessive forward movement of the condyle beyond the articular eminence with complete separation of the articular surfaces and fixation in that position. ${ }^{4-7)}$ The patient with the dislocated joint is unable to close the mouth with or without pain and this can occur as a single or chronic recurrent episode.

The mechanism of the TMJ open lock is closely related to the structure and function of the TMJ as well as the masticatory muscular system. The capsule of the joint is the most important structure that plays a role in TMJ open lock because it stabilizes the joint reinforced by the lateral ligaments. ${ }^{4,5}$ \{Sindet-Pedersen, 1988 \#3\} The displacement of the head of the condyle out of the 
glenoid fossa is also greatly influenced by the morphology of the condyle, glenoid fossa, articular eminence, zygomatic arch and squamotympanic fissure. In addition, age, dentition, cause and duration of the dislocation as well as the function of the masticatory muscles contribute significantly in the mechanism and management of TMJ open lock. ${ }^{5}$

The previous studies have highlighted the predisposing and etiological factors for condyle dislocations, such as poor development of the articular fossa, laxity of the temporomandibular ligament or joint. ${ }^{6)}$ Based on such factors, various therapeutic approaches such as the introduction of a sclerosing agent into the capsular space of the TMJ, scarification of the temporalis tendon, bone grafting augmentation of articular eminence have been applied to limit the forward excursion of condyle head. ${ }^{4,-9)}$ However, the exact mechanism and the definitive treatment of the TMJ open lock are practically unclear, yet.

The aim of this study was to investigate the skeletal factors related to the TMJ open lock in terms of the review and comparison of the radiographic and clinical data of the patients with TMJ open lock, TMD patients without open lock, and normal subjects.

\section{П. MATERIALS AND METHODS}

\section{Subjects}

The clinical and radiographic record of fifty patients who visited the Department of Oral Medicine of the Seoul National University Dental Hospital complaining of TMJ open lock from January 2008 to June 2012 were consecutively filed and reviewed retrospectively. The records of patients as follows were enrolled to open lock group; a patient coming for reduction of present open lock; a patient complaining of open lock episodes more than one time within recent 1 year as his/her chief complain, no present open lock state, though; a patient reporting open lock episode within recent 1 year on a diagnostic procedure of TMD related symptoms presented as his/her chief complain. For the comparative analysis, two types of control group were made by random selection of the clinical records from the pool of outpatient records in an age-and-gender-matched way with open lock group. One is TMD group consisting of 50 patients with TMD diagnosed based on RDC/TMD Axis I and without any open lock history or sign. The other is normal group consisting of 50 patients without open lock or any TMD related symptoms. For the age-and-gender-matched random selection, all of TMD patients with the same gender and age by the decade were filtered first from the pool of all of TMD patients visiting the same establishment during the same period with open lock patients, and then, the same number of subjects with the relevant open lock patients were randomly selected from the filtered pool of TMD patients. Subjects of normal group were selected from the patients visiting the same establishment complaining of problems not related to TMD and presenting no history or sign related to TMD in the same manner with TMD group. The Records of the patients who had history or any sign of inflammatory joint disease, trauma, and maxillofacial surgery that can affect the TMJ were excluded from the study. This study protocol was approved by the Institutional Review Board of Seoul National University Dental Hospital (CRI12015).

\section{Radiographic Analysis}

Skeletal differences among 3 groups were analyzed on the radiographs of cephalogram and transcranial radiographs. The reference points and linear and angular measurements used to investigate the relationship among the skull base, maxilla, and mandible were listed and shown in Fig. 1 and 2. The height and inclination of the articular eminence were calculated on the transcranial radiographs as previously described. ${ }^{10)}$ Taking transcranial radiographs, patients were instructed to take a position to keep their Frankfort plane parallel to the horizontal plane approximately by guidance of stick 


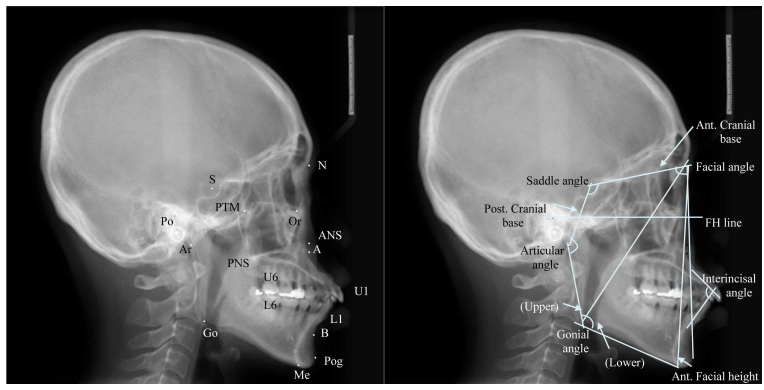

Fig. 1. The landmark point of measurement of dentocraniofacial morphologic feature in lateral cephalogram

$N$ : Nasion

$S$ : Sella turcica

Po : Porion

Or : Orbitale

PTM : Pterygomaxillary fissure

ANS : Anterior nasal spine

PNS : Posterior nasal spine

A : A point

B : B point

U1: Upper incisor

L1 : Lower incisor

U6 : Upper first molar

L6 : Lower first molar

Pog : Pogonion

Me : Menton

Ar : Articulare

Go : Gonion

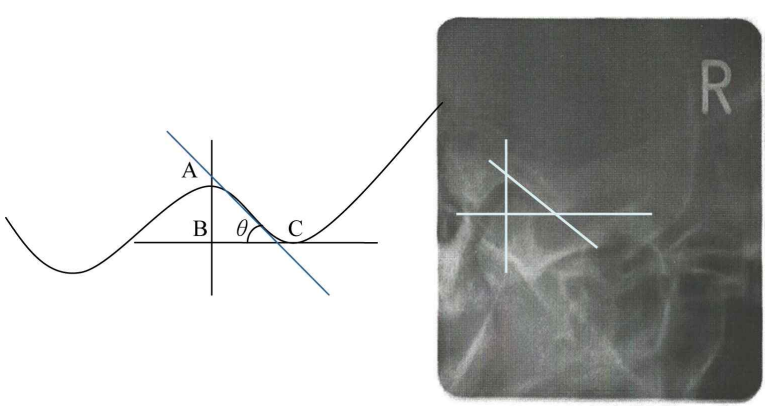

Fig. 2. The reference points of estimation of articular eminence

BC : parallel to Frankfort plane

$A C$ : anterior surface of articular eminence

$\theta$ : angles present a measure of articular eminence inclination pins put into the ears. So we measured the inclination and height of the eminence referring to the horizontal line in radiographs. For the measurements, a line fitting the best the posterior surface of the articular eminence (anterior surface of the fossa) was drawn and the angle between the line and the horizontal line were measured as the inclination of the articular eminence. ${ }^{10)}$

\section{Statistical Analysis}

The mean differences of measures among groups were analyzed in terms of ANOVA with Bonferroni test as a post hoc test.

\section{RESULTS}

From the results of cephalometric analysis, open lock group turned out to have smaller saddle angle and longer anterior cranial base than normal group, while TMD group have longer anterior cranial base and larger $\mathrm{ANB}$ angle than normal group. No significant difference of measurement was observed between open lock and TMD group by Bonferroni post hoc test.

In transcranial radiograph, open lock group have steeper inclination of the eminence than normal group. Despite that significant difference between open lock and TMD group was observed only in the right TMJ, the measures of the left TMJ of TMD group was likely to be closer to that of normal group than open lock group.

\section{DISCUSSION}

This study was carried out to evaluate the skeletal feature of open lock patients. When the jaw is locked open, the condyle is entrapped to the eminence out of the articular fossa and the patient manifests an inability to close the mouth, preauricular pain, and masticatory muscle tenderness. The etiology of TMJ open lock can be traumatic, prolonged mouth opening, ligament or capsular laxity, internal joint derangement, neuromuscular, or psychogenic. ${ }^{11-13)}$ Treatment 
Table 1. Age and gender distribution of open lock group and control group

\begin{tabular}{|c|c|c|c|c|c|c|}
\hline \multirow[b]{2}{*}{ Age $\backslash$ Gender } & \multicolumn{2}{|c|}{ Open lock } & \multicolumn{2}{|c|}{ TMD } & \multicolumn{2}{|c|}{ Normal } \\
\hline & Male & Female & Male & Female & Male & Female \\
\hline 10 's & 3 & 9 & 3 & 9 & 3 & 9 \\
\hline 20 's & 8 & 18 & 8 & 18 & 8 & 18 \\
\hline 30 's & 1 & 4 & 1 & 4 & 1 & 4 \\
\hline 40 's & 2 & 2 & 2 & 2 & 2 & 2 \\
\hline 50 's & & 2 & & 2 & & 2 \\
\hline \multicolumn{7}{|l|}{60 's } \\
\hline 70 's & & 1 & & 1 & & 1 \\
\hline Total & \multicolumn{2}{|c|}{50} & \multicolumn{2}{|c|}{50} & \multicolumn{2}{|c|}{50} \\
\hline
\end{tabular}

methods are directed to either limit the forward movement of the condylar head or enable free back-and-forth sliding, preventing it from locking anterior to the steep articular eminence. ${ }^{14)}$ But the cause and mechanisms of open lock is unclear, ${ }^{15)}$ the management of TMJ open lock is controversial: many advocate conservative treatment, whereas others believe surgery can improve the symptoms and prevent recurrence of open lock. ${ }^{16)}$

Fukui at al. described that the inclination of the mandibular ramus on the sagittal plane is the most important factor influencing jaw opening. The greater the ramus inclination is, the wider the counterclockwise rotation of both of the ramus and the condyle, thus affecting jaw opening. ${ }^{17)}$ Nitzan et al. suggested the recurrent dislocation, open lock, is considered to occur most frequently in patients with deep overbite combined with steep articular tubercles. ${ }^{14)}$ Tuijt et al. reported that the direction of a joint reaction force is heading perpendicular to the surface of the eminence at the point of contact with the mandibular condyle, since the problem of open lock occurs anterior of the eminence, on only the anterior slope angle of the eminence was considered to be relevant. ${ }^{18)}$ We investigated how this angle, in combination with patient's skeletal features, might contribute to the susceptibility for an open lock, based on the cephalometric analysis and measurements on transcranial radiographs.

In this study, symptomatic patients were clinically diagnosed based on the RDC/TMD Axis I and all patients were taken lateral cephalogram and transcranial radiograph in the diagnostic procedure. The skeletal features such as cranial base relationship, maxilla-mandibular relationship, and vertical skeletal relationship were investigated on lateral cephalogram in terms of landmarks listed and shown in Figure 1. The saddle angle is an angle between nasion(N)-sella(S) and sella(S)-artuculare (Ar), which reflects the flexure between the anterior and posterior cranial base and the position of the temporomandibular fossa. ${ }^{19)}$ The smaller saddle angle means the mandible is located in more anterior position. The short anterior cranial base and small ANB(less than 2) means anteriorly positioned mandible. ${ }^{20)}$ In the results, open lock group have smaller saddle angle and longer anterior cranial base than normal group, while TMD group also have longer anterior cranial base than normal group. Because other cephalometric measures were not significant between open lock group and normal group and longer anterior cranial base can be observed in TMD group without open lock, it can be postulated that the only skeletal feature on cephalometic analysis related to open lock occurrence is the TMJ positioned to more anterior 
Table 2. Means and results of students t-test for comparison between groups

\begin{tabular}{|c|c|c|c|c|c|}
\hline & Open lock (A) & TMD (B) & Normal (C) & \multicolumn{2}{|c|}{ Significance } \\
\hline Saddle angle & $123.4 \pm 9.2$ & $125.2 \pm 5.1$ & $127.1 \pm 4.9$ & * & $(\mathrm{A}, \mathrm{C})$ \\
\hline Articular angle & $141.2 \pm 27.0$ & $142.8 \pm 11.3$ & $141.0 \pm 9.5$ & - & - \\
\hline Gonial angle & $126.7 \pm 19.2$ & $124.5 \pm 31.6$ & $126.9 \pm 22.4$ & - & - \\
\hline Sum & $391.2 \pm 52.3$ & $392.5 \pm 40.0$ & $394.9 \pm 30.0$ & - & - \\
\hline Ant. Cranial base & $70.6 \pm 3.6$ & $70.5 \pm 3.5$ & $68.6 \pm 4.2$ & * & $(\mathrm{A}, \mathrm{C}),(\mathrm{B}, \mathrm{C})$ \\
\hline Post. Cranial base & $40.8 \pm 15.1$ & $38.7 \pm 4.2$ & $38.1 \pm 3.9$ & - & - \\
\hline Gonial angle(upper) & $45.4 \pm 18.2$ & $48.6 \pm 4.8$ & $47.5 \pm 4.3$ & - & - \\
\hline Gonial angle(lower) & $81.3 \pm 4.2$ & $76.0 \pm 34.6$ & $79.5 \pm 20.1$ & - & - \\
\hline SNA & $80.3 \pm 4.5$ & $80.7 \pm 3.8$ & $78.9 \pm 4.2$ & - & - \\
\hline SNB & $77.9 \pm 4.3$ & $77.4 \pm 3.4$ & $77.2 \pm 4.6$ & - & - \\
\hline ANB & $2.4 \pm 3.0$ & $3.3 \pm 2.5$ & $1.8 \pm 3.4$ & $*$ & $(\mathrm{~B}, \mathrm{C})$ \\
\hline Ant. Facial height & $134.9 \pm 7.9$ & $133.0 \pm 6.8$ & $132.5 \pm 7.7$ & - & - \\
\hline Facial plane angle & $78.5 \pm 4.4$ & $77.9 \pm 3.5$ & $77.5 \pm 4.8$ & - & - \\
\hline Facial convexity & $3.6 \pm 6.4$ & $5.6 \pm 6.0$ & $2.8 \pm 8.1$ & - & - \\
\hline FMIA & $58.2 \pm 8.7$ & $57.7 \pm 7.5$ & $57.9 \pm 10.2$ & - & - \\
\hline Interincisal angle & $119.3 \pm 12.7$ & $118.4 \pm 9.3$ & $118.5 \pm 12.1$ & - & - \\
\hline $\mathrm{U} 1$ to $\mathrm{FH}$ & $118.9 \pm 9.1$ & $119.3 \pm 5.8$ & $119.4 \pm 7.4$ & - & - \\
\hline $\mathrm{U} 1$ to $\mathrm{SN}$ & $109.6 \pm 9.0$ & $110.0 \pm 5.9$ & $110.2 \pm 7.8$ & - & - \\
\hline U1 to facial plane & $10.4 \pm 3.8$ & $10.7 \pm 4.1$ & $10.5 \pm 5.0$ & - & - \\
\hline L1 to facial plane & $6.8 \pm 3.0$ & $6.4 \pm 3.5$ & $6.7 \pm 4.2$ & - & - \\
\hline Right eminence inclination & $49.1 \pm 9.0$ & $43.4 \pm 11.7$ & $43.5 \pm 11.2$ & $*$ & $(\mathrm{~A}, \mathrm{~B}),(\mathrm{A}, \mathrm{C})$ \\
\hline Left eminence inclination & $48.4 \pm 10.9$ & $44.0 \pm 13.1$ & $42.4 \pm 10.3$ & $*$ & $(\mathrm{~A}, \mathrm{C})$ \\
\hline
\end{tabular}

Differences among groups were analyzed by ANOVA and Bonferroni test as a post hoc test.

$*$ : Significant difference by ANOVA, $*$ : $\mathrm{P}<0.05, * *$ : $\mathrm{P}<0.01, * * *: \mathrm{P}<0001$.

Pairs represent pairs with significant difference proved by Bonferroni test

than the normal based on the smaller saddle angle. When the jaw closes, active closing forces exerted by the muscles are only toward the cranial base, in other words, there is no muscle to pull back the joint to the fossa. Taking this fact into consideration, the joint position more anterior to other structures can result the joint more close to the axis of the forces exerted by the closing muscles, and then it can push the joint toward the cranial base too much for the passive backward force by ligaments to pull back the joint into the fossa over the eminence, resulting open lock.

For radiographic imaging of the human TMJ, the transcranial radiograph shows the condyle-fossa positional relationship and anterior movement of condyle at mouth opening. And this is an excellent and inexpensive method for detection of structural changes in lateral position of joint. A clinical crucial, 
but also limiting, aspect of transcranial radiograph is that it only depicts the mineralized components of the lateral one-third of the TMJ., ${ }^{8,21,22)}$ Keesler et al. found that there were no significant differences between the photographic and radiographic lateral eminence angles on the right and left sides. ${ }^{22)}$ In this study transcranial radiograph was used to examine articular eminence inclination. Because, taking transcranial radiographs, patients are instructed to take a position with their Frankfort plane approximately parallel to the horizontal plane, the horizontal line in radiograph was used as a reference line in the measurement. In the result, the inclination of the articular eminence measured in terms of the method introduced by Katsavria et al. ${ }^{10)}$ was steeper in open lock group than in TMD and normal group. This result implies that patients with steeper articular eminence are riskier to TMD open lock, and in concordance with the previous studies that poor development associated TMD open lock $^{7)}$ and recurrent mandibular dislocation mainly occurred in patients with a steep articular eminence. ${ }^{23-27)}$

This study examined the skeletal features of TMJ open lock patients using lateral cephalogram and transcranial radiograph analysis. The saddle angle is smaller in open lock group on cephalograms than in normal group and inclination of the articular eminence is steeper in open lock group on transcranial radiographs than in TMD and normal groups. These findings suggest that the patients with the joint located more anterior and the articular eminence with steeper inclination might be riskier to TMJ open lock.

\section{REFERENCE}

1. Bagis B, Ayaz EA, Turgut S, Durkan R, Ozcan M. Gender difference in prevalence of signs and symptoms of temporomandibular joint disorders: a retrospective study on 243 consecutive patients. Int $\mathrm{J}$ Med Sci 2012;9:539-544.

2. Gomes NC, Berni-Schwarzenbeck KC, Packer AC, Rdrigues-Bigaton D. Effect of cathodal high-voltage electrical stimulation on pain in women with TMD. Rev Bras Fisioter 2012;16:10-15.
3. Costa AL, Campos LS, Franca Jr MC, D'Abreu A. Temporomandibular disorders in patients with craniocervical dystonia. Arq Neuropsiquiatr 2011;69: 896-899

4. Sindet-Pedersen S. Intraoral myotomy of the lateral pterygoid muscle for treatment of recurrent dislocation of the mandibular condyle. J Oral Maxillofac Surg 1988;46:445-449.

5. Akinbami BO. Evaluation of the mechanism and principles of management of temporomandibular joint dislocation. Systematic review of literature and a proposed new classification of temporomandibular joint dislocation. Head Face Med 2011;7:10.

6. Ugboko VI, Oginni FO, Ajike SO, Olasoji HO, Adebayo ET. A survey of temporomandibular joint dislocation: aetiology, demographics, risk factors and management in 96 Nigerian cases. Int J Oral Maxillofac Surg 2005;34:499-502.

7. Vasconcelos BC, Porto GG, Neto JP, Vasconcelos CF. Treatment of chronic mandibular dislocations by eminectomy: follow-up of 10 cases and literature review. Med Oral Patol Oral Cir Bucal 2009;14: e593-596.

8. Preti G, Bruscagin C, Scotti R, Cardesi E. Statistical study of the angle formed by the lateral part of the mandibular condyle and the horizontal plane. J Prosthet Dent 1983;50:571-575.

9. Luyk NH, Larsen PE. The diagnosis and treatment of the dislocated mandible. Am J Emerg Med 1989;7: 329-335

10. Katsavrias EG. Changes in articular eminence inclination during the craniofacial growth period. Angle Orthod 2002;72:258-264.

11. Torres DE, McCain JP. Arthroscopic electrothermal capsulorrhaphy for the treatment of recurrent temporomandibular joint dislocation. Int $\mathrm{J}$ Oral Maxillofac Surg 2012;41:681-689.

12. Baur DA, Jannuzzi JR, Mercan U, Quereshy FA. Treatment of long term anterior dislocation of the TMJ. Int J Oral Maxillofac Surg 2013.

13. Mayrink G, Olate S, Assis A, Sverzut A, de Moraes M. Recurrent mandibular dislocation treated by eminectomy. J Craniofac Surg 2012;23:e516-520.

14. Nitzan DW. Temporomandibular joint "open lock" versus condylar dislocation: signs and symptoms, imaging, treatment, and pathogenesis. J Oral Maxillofac Surg 2002;60:506-511; discussion 512-503.

15. Kai S, Kai H, Nakayama E, et al. Clinical symptoms of open lock position of the condyle. Relation to 
anterior dislocation of the temporomandibular joint. Oral Surg Oral Med Oral Pathol 1992;74:143-148.

16. Taglialatela Scafati C, Taglialatela Scafati S. Role of orthognathic surgery in the treatment of recurrent mandibular dislocation: importance of mandibular ramus inclination. J Craniofac Surg 2012;23:e420-423.

17. Fukui T, Tsuruta M, Murata K, et al. Correlation between facial morphology, mouth opening ability, and condylar movement during opening-closing jaw movements in female adults with normal occlusion. Eur J Orthod 2002;24:327-336.

18. Tuijt M, Koolstra JH, Lobbezoo F, Naeije M. Biomechanical modeling of open locks of the human temporomandibular joint. Clin Biomech (Bristol, Avon) 2012;27:749-753.

19. Jarvinen S. Saddle angle and maxillary prognathism: a radiological analysis of the association between the NSAr and SNA angles. Br J Orthod 1984;11:209-213.

20. Mestriner Junior W, Valente A. [Facial prognathism and its relation to the cranial base in Brazilian children with Class I malocclusion]. Rev Odontol Univ Sao Paulo 1989;3:324-333.
21. Van Sickels JE, Bianco HJ, Jr., Pifer RG. Transcranial radiographs in the evaluation of craniomandibular (TMJ) disorders. J Prosthet Dent 1983;49:244-249.

22. Keesler JT, Christensen LV, Donegan SJ, Austin BP. A transcranial radiographic examination of the temporal portion of the temporomandibular joint. J Oral Rehabil 1992;19:71-84.

23. Undt G. Temporomandibular joint eminectomy for recurrent dislocation. Atlas Oral Maxillofac Surg Clin North Am 2011;19:189-206.

24. Manfredini D. Etiopathogenesis of disk displacement of the temporomandibular joint: a review of the mechanisms. Indian J Dent Res 2009;20:212-221.

25. Atkinson WB, Bates RE, Jr. The effects of the angle of the articular eminence on anterior disk displacement. J Prosthet Dent 1983;49:554-555.

26. Hall MB, Gibbs CC, Sclar AG. Association between the prominence of the articular eminence and displaced TMJ disks. Cranio 1985;3:237-239.

27. Kerstens HC, Tuinzing DB, Golding RP, Van der Kwast WA. Inclination of the temporomandibular joint eminence and anterior disc displacement. Int J Oral Maxillofac Surg 1989;18:228-232. 


\title{
국문초록
}

\section{측두하악관절의 개구성 과두걸림 환자의 골격적 특성에 관한 연구}

\author{
남지나·이정윤 \\ 서울대학교 치과대학 구강내과학교실
}

본 연구는 측두하악관절의 개구성 과두걸림과 골격적 특성 사이의 연관성을 분석하고자 개구성 과두걸림 환자를 대상으로 측두두부방사선 사진과 횡두개촬영 방사선 사진을 이용하여 두개골의 골격적 특성 및 관절 융기의 기울기를 비교 분석하였 다.

개구성 과두걸림 환자를 환자군으로 하고 개구성 과두걸림은 없지만 측두하악장애 연구진단 기준(Research Diagnostic Criteria for Temporomandibular Disorder; RDC/TMD) Axis I에 따라 측두하악장애으로 진단된 환자를 측두하악장애 환자 군, 개구성 과두걸림과 측두하악장애가 모두 없는 정상 환자를 정상군으로 설정하고 순차적으로 수집된 환자군 50 명과 성별 및 연령이 일치하도록 무작위로 측두하악장애 환자군과 정상군, 각각 50 명의 임상기록을 선별하였다. 측두하악장애에 영향을 줄 수 있는 관절염이나 외상의 병력, 악안면 기형, 악안면 수술 병력이 있는 환자는 모두 제외하였다. 세 군의 측두두부규격방 사선 사진과 횡두개촬영 방사선 사진을 분석하여 골격적 특성과 관절 융기의 기울기를 측정하였다.

두개골과 하악과의 골격적 특성을 나타내는 측두두부방사선 사진을 분석한 결과 개구성 과두걸림이 있는 환자군에서 하악의 전후방적 위치를 나타내어주는 saddle angle이 더 작은 것으로 나타났으며 이는 두개골에 대해 하악이 더 전방으로 위치하고 있음을 나타낸다. 또한 횡두개촬영 방사선 사진상에서는 개구성 과두걸림 환자군이 측두하악장애 환자군과 정상군보다 관절 융기의 기울기가 더 크게 관찰되었다.

이러한 결과는 두개골에 대해 측두하악관절이 더 전방으로 위치하고 관절 융기가 더 급한 경사를 가질 경우 개구성 과두걸 림이 발생할 가능성이 더 크다는 것을 의미한다.

주제어: 측두하악관절, 측두하악장애, 관절융기, 폐구제한, 탈구 